\title{
ASSESSING GREEN PROPERTY MANAGEMENT IMPLEMENTATION AMONG COMMERCIAL BUILDINGS IN MALAYSIA
}

\author{
MUHAMMAD NAJIB RAZALI \& M8 +\$0 0 \$ ' YUS\$, 0 , HAMID \\ Universiti Teknologi Malaysia, Malaysia
}

\begin{abstract}
The implementation of the Green Property Management (GPM) by the building manager for an office building is important for the sustainability of nature and living mechanism. However, the lack of guidelines or green management framework is preventing the property managers from applying the green management concept. The practice of GPM is not totally adopted in Malaysia. The aforementioned points highlight some of the problems arising from the successful implementation of the Green Building Index. Controlling the professional practice towards green management, the documenting of specific rules for practice and the standards for practice are some of the requirements for GPM to operate. In formulating the framework for GPM, there is a need to determine the structure for operation of the GPM practice. There must also be a body to which legal power is given to oversee the smooth operation of the practice. The adoption of operational standards as determined earlier must be the guide for its implementation by property managers.
\end{abstract}

Keywords: building, green, property management, Malaysia.

\section{INTRODUCTION}

This research examines the practice of Green Property Management (GPM) in Malaysia. Green property concept is relatively new concept in property although it has been widely used in other areas [1]. Property Management is the process of taking care of properties so as to meet the interest of all people having interest in property. According to the Hong Kong productivity council [2], green property management are driven by the new business model which takes into consideration sustainable measures to manage buildings in urban areas since it is one of the largest contributors to carbon emission. The extent of damage to the environment from unsustainable living today has influenced building users and operators to adopt a more environmental practice towards property asset management. Nevertheless, practice for GPM has been experiencing mixed understanding on its concept and hence, there is no standard practice towards using its guidelines. Practicing GPM appears to be piecemeal with many organisations as it provides some guidelines on how to be sustainable in building management.

Sustainable measures through green property management were suggested to be the solution to the problems of urban decay caused by the unsustainable use of buildings. Some measures taken to go green in property management are the construction of new buildings that observe the green criteria or green buildings. However, in many cities, the environment is littered with unsustainable buildings and this seems to be a major problem all over the world. The construction of these buildings must adopt the green property management, which reduces the impact of pollution to the environment. Research in this area suggest that efforts towards attaining sustainable use of buildings includes the promotion of the green property management aspects through waste management and use of energy efficient equipment [3]. Green property management adopts a holistic view of the environmental impacts due to the various activities of building users and the need to balance human needs with the ecological concerns. 
The approach to GPM particularly in Malaysia suggests that there is a need for a proper framework to practice GPM. This involves the commitment of those involved in the buildings; every party must understand and be willing to change for the betterment of the world environment. The lists may include naming a few, building managers, owners, relevant authorities, investors, tenants and others dealing with buildings. The commitments of those involved will include having pre-empted knowledge, planning and actions to be taken by the different parties. There is indeed a need to define the working system in GPM to be followed. Since going green is about performance measurement, there is also a need to define what measurements are desired. The current rules of the green building in Malaysia or the Green Building Index (GBI) adopted some form of green performance measurement towards an award achievement for the green building status. The award of the green status is bounded by relevant rules and have to be observed by building owners to maintain their green status. In moving towards GPM, there have to be similar rules imposed to everyone; this would require interest and support for all new and ongoing procedures that are developed. Similarly, performance measurement may be required.

In this research, the procedures and methods of developing the green property management framework examines some of the above requirements for the practice of GPM. In particular it examines the work procedures in current property management practice by property professionals and to integrate performance measurement by the GBI in designing the framework for GPM practice.

\section{LITERATURE REVIEW}

The sustainability concept has taken on an increased importance in recent years, with awareness becoming more widespread in many disciplines. Due to the industrialisation process that has taken place in many countries, the concept of sustainability in countries' development has become more important. As such many countries introduced sustainable development concept as a main national policy. Sustainable development issues arise from environmental problems, resulting in pollution and damage to the earth. Through industrialisation and globalisation, the standard of living in the developed world has soared from bare subsistence to affluence, while the majority of people in the developing world remain subject to destitution [4]. Due to an increase in awareness of the need to minimise the impact of development on the environment, the concept of sustainable development has been introduced. Sustainable development concept comprises of three pillars which consist of economy, social and environmental. In theory, sustainable development is defined in terms of the pattern of structural changes in natural and man-made capital stock, inclusive of human capital and technological capabilities, which ensures the feasibility of at least a minimum socially desired rate of growth in the long run [5]. With environmental concerns demanding more consideration in development, the sustainability concept has become a national issue. As most countries become even more developed, physical development is a necessity to meet the physical space of demand and supply. Consequently, real estate sector emerges as the main sector in many countries concurrent with the country's development. According to Goodland [6], environmental sustainable is defined as 'seeks to improve human welfare by protecting the sources of raw materials used for human needs and ensuring that the sinks for human wastes are not exceeded, in order to prevent harm to humans'. Environmental sustainable is focusing on bio geophysical aspect which means maintaining or improving the integrity of the life supporting systems of the Earth [7].

With the sustainable concept arising in many countries, all projects need to take into account sustainable features such as the modelling of elevations and choice of materials. There is no doubt that applying the sustainability concept to development projects will 
benefit not only organisations but also their parent-countries, through better monetary returns, an improved image among communities, and reduced damaging effects to the environment. Nevertheless, organisations should conduct a cost benefit analysis before applying this concept to their projects.

In countries' development process, real estate sector plays a major role. This is due to the need for physical space to run the countries' economic activities. As a result, real estate has become the catalyst in the economic growth of a country. Unfortunately, the real estate sector has been recognised as a major contributor to the global environment degradation because it involves several activities such as construction, the built environment, and the building management. According to Shiers et al. [8], the property industry has a major impact on the environment, with buildings contributing up to $50 \%$ of $\mathrm{CO}_{2}$ emissions, $40 \%$ of energy requirements, $16 \%$ of water usage, $40 \%$ of solid landfil 1 was te, $50 \%$ of raw materials and $71 \%$ of electricity consumption. Therefore, it is crucial that the concept of sustainability be enforced in the real estate sector. Another recent trend involves the emergence of new concepts in real estate such as "green property management", "green building", "sustainable housing", "sustainable property" and "sustainable property finance". Sustainability in real estate can be defined as those services offered by all stakeholders in the property business that aim to enhance and sustain the concept of real estate and sustainability. The activities in real estate that contribute to the environmental problem stems from the property developers who are the main players in the property business.

Activities by any property sector involving building construction and operation will result in a major impact on the environment. According to Wilkinson [9], the built environment is responsible for around half of all greenhouse emissions. Newell and Manaf [10] mentioned, buildings contribute up to $50 \%$ of carbon dioxide emissions, $40 \%$ of energy requirements, $16 \%$ of water usage, $40 \%$ of solid landfill waste, $50 \%$ of raw materials and $71 \%$ of electricity consumption. From the sustainability point of view, this information indicates that the property sector needs to reduce the impact on the environment.

The result of the survey is presented in Tables $1-10$.

Table 1: Demography of respondents.

\begin{tabular}{lll}
\hline No. & Respondents & Percentage \\
\hline 1. & Property manager & $51 \%$ \\
2. & Building surveyor & $20 \%$ \\
3. & Director/Manager & $9 \%$ \\
4. & Deputy Director/Manager & $14 \%$ \\
5. & Officer & $6 \%$ \\
& Total 158 & $100 \%$ \\
\hline
\end{tabular}

Table 2: General aspects of Green Property Management.

\begin{tabular}{lllll}
\hline No. & & Yes & No & Sometime \\
\hline 1. & $\begin{array}{l}\text { Are you keen on green property } \\
\text { management practice? }\end{array}$ & $85 \%$ & $15 \%$ & $0 \%$ \\
& & & \\
2. & Do you have a green policy? & $56 \%$ & $44 \%$ & $0 \%$ \\
3. & $\begin{array}{l}\text { Does the following drive you to } \\
\text { go green in property management? }\end{array}$ & & \\
a. & Economic incentives/disincentives & $59 \%$ & $11 \%$ & $30 \%$ \\
b. & Legal pressure & $26 \%$ & $69 \%$ & $5 \%$ \\
c. & Political & $6 \%$ & $83 \%$ & $11 \%$ \\
d. & Social & $21 \%$ & $68 \%$ & $11 \%$ \\
e. & Others & - & - & - \\
\hline
\end{tabular}


Table 3: Preparation of management plans.

\begin{tabular}{|c|c|c|c|c|}
\hline 1. & $\begin{array}{l}\text { Do you consider energy efficiency } \\
\text { in your management plans? }\end{array}$ & $84 \%$ & $5 \%$ & $11 \%$ \\
\hline 2. & $\begin{array}{l}\text { Do you have minimum energy } \\
\text { efficiency performance measure? }\end{array}$ & $62 \%$ & $34 \%$ & $4 \%$ \\
\hline 3. & $\begin{array}{l}\text { Do you provide for energy } \\
\text { management control system? }\end{array}$ & $61 \%$ & $32 \%$ & $7 \%$ \\
\hline 4. & $\begin{array}{l}\text { Do you provide flexible lighting } \\
\text { controls to optimise energy } \\
\text { savings? }\end{array}$ & $63 \%$ & $15 \%$ & $22 \%$ \\
\hline 5. & $\begin{array}{l}\text { Do you provide electrical metering } \\
\text { and sub metering? }\end{array}$ & $98 \%$ & $2 \%$ & $0 \%$ \\
\hline 6. & $\begin{array}{l}\text { Do you have enhanced } \\
\text { commissioning of building energy } \\
\text { system? }\end{array}$ & $51 \%$ & $22 \%$ & $27 \%$ \\
\hline \multicolumn{5}{|c|}{ Indoor air quality } \\
\hline 1. & $\begin{array}{l}\text { Do you control environmental } \\
\text { from tobacco smoke? }\end{array}$ & $71 \%$ & $15 \%$ & $14 \%$ \\
\hline 2. & $\begin{array}{l}\text { Do you monitor and control } \\
\text { Carbon monoxide? }\end{array}$ & $62 \%$ & $22 \%$ & $16 \%$ \\
\hline 3. & $\begin{array}{l}\text { Do you control indoor air pollutant } \\
\text { from finishes that emits internal air } \\
\text { pollutant? }\end{array}$ & $26 \%$ & $58 \%$ & $16 \%$ \\
\hline 4. & $\begin{array}{l}\text { Do you have mould prevention } \\
\text { measures? }\end{array}$ & $77 \%$ & $15 \%$ & $8 \%$ \\
\hline 5. & $\begin{array}{l}\text { Do you allow thermal comfort } \\
\text { through design and controllability } \\
\text { of system? }\end{array}$ & $82 \%$ & $18 \%$ & $0 \%$ \\
\hline 6. & $\begin{array}{l}\text { Do you control air change } \\
\text { effectiveness to create healthy } \\
\text { indoor environment? }\end{array}$ & $76 \%$ & $11 \%$ & $13 \%$ \\
\hline 7. & $\begin{array}{l}\text { Do you control lighting, visual \& } \\
\text { acoustic comfort? }\end{array}$ & $72 \%$ & $17 \%$ & $11 \%$ \\
\hline \multicolumn{5}{|c|}{ Materials and resources } \\
\hline 1. & $\begin{array}{l}\text { Are there storage and recyclables } \\
\text { systems in this building? }\end{array}$ & $84 \%$ & $15 \%$ & $1 \%$ \\
\hline 2. & $\begin{array}{l}\text { Do you have } 3 \text { Rs Initiatives and } \\
\text { Bin provision? }\end{array}$ & $77 \%$ & $19 \%$ & $4 \%$ \\
\hline \multicolumn{5}{|c|}{ Water efficiency } \\
\hline 1. & $\begin{array}{l}\text { Do you facilitate water saving } \\
\text { program? }\end{array}$ & $94 \%$ & $6 \%$ & $0 \%$ \\
\hline 2. & $\begin{array}{l}\text { Do you have rain water harvesting } \\
\text { to reduce water consumption? }\end{array}$ & $24 \%$ & $76 \%$ & $0 \%$ \\
\hline 3 & Do you water efficiency measures? & $5 \%$ & $95 \%$ & $0 \%$ \\
\hline \multicolumn{5}{|c|}{ Innovation } \\
\hline 1. & $\begin{array}{l}\text { Did you set up innovation } \\
\text { programs to encourage green } \\
\text { practices? }\end{array}$ & $4 \%$ & $93 \%$ & $3 \%$ \\
\hline 2. & $\begin{array}{l}\text { Do you have Car Park Policy to } \\
\text { ensure that } 10 \% \text { of parking bays } \\
\text { are for hybrid cars (station)? }\end{array}$ & $3 \%$ & $97 \%$ & $0 \%$ \\
\hline
\end{tabular}


Table 4: Building management.

\begin{tabular}{|c|c|c|c|c|}
\hline \multicolumn{5}{|c|}{ Building efficiency } \\
\hline 1. & $\begin{array}{l}\text { Do you ensure there are energy } \\
\text { efficiency rules in building } \\
\text { management? }\end{array}$ & $62 \%$ & $20 \%$ & $43 \%$ \\
\hline 2. & Is there SOP for energy efficiency? & $63 \%$ & $15 \%$ & $22 \%$ \\
\hline 3. & $\begin{array}{l}\text { Waste management - DOE } \\
\text { guidelines, UBBL, KETTHA }\end{array}$ & $74 \%$ & $20 \%$ & $6 \%$ \\
\hline 4. & $\begin{array}{l}\text { Is there a formulation of green } \\
\text { management maintenance } \\
\text { procedures }\end{array}$ & $11 \%$ & $73 \%$ & $16 \%$ \\
\hline \multicolumn{5}{|c|}{ Indoor air quality } \\
\hline 1. & $\begin{array}{l}\text { Do you accommodate indoor air } \\
\text { quality performance? }\end{array}$ & $27 \%$ & $67 \%$ & $6 \%$ \\
\hline \multicolumn{5}{|c|}{ Materials and resources } \\
\hline 1. & $\begin{array}{l}\text { To include in SOP the use of } \\
\text { biodegradable materials? }\end{array}$ & $18 \%$ & $75 \%$ & $7 \%$ \\
\hline \multicolumn{5}{|c|}{ Water efficiency } \\
\hline 1. & $\begin{array}{l}\text { Do you include water efficiency } \\
\text { measures? }\end{array}$ & $76 \%$ & $23 \%$ & $1 \%$ \\
\hline
\end{tabular}

Table 5: Maintenance management.

\begin{tabular}{|c|c|c|c|c|}
\hline \multicolumn{5}{|c|}{ Energy efficiency } \\
\hline 1. & $\begin{array}{l}\text { Do you manage of energy } \\
\text { saving devices? }\end{array}$ & $56 \%$ & $23 \%$ & $21 \%$ \\
\hline 2. & $\begin{array}{l}\text { Do you maintain energy } \\
\text { efficiency measures? }\end{array}$ & $55 \%$ & $16 \%$ & $29 \%$ \\
\hline 3. & $\begin{array}{l}\text { Do you include green } \\
\text { consideration in services by } \\
\text { service providers? }\end{array}$ & $57 \%$ & $15 \%$ & $28 \%$ \\
\hline \multicolumn{5}{|c|}{ Indoor air quality } \\
\hline 1. & $\begin{array}{l}\text { Do you maintain indoor air } \\
\text { quality devices? }\end{array}$ & $21 \%$ & $77 \%$ & $2 \%$ \\
\hline \multicolumn{5}{|c|}{ Materials and resources } \\
\hline 1. & $\begin{array}{l}\text { To adopt strictly on green } \\
\text { materials that is non-abrasive } \\
\text { for maintenance? }\end{array}$ & $17 \%$ & $82 \%$ & $1 \%$ \\
\hline \multicolumn{5}{|c|}{ Water efficiency } \\
\hline 1. & $\begin{array}{l}\text { Do you maintain waters saving } \\
\text { devices including water } \\
\text { harvesting system? }\end{array}$ & $6 \%$ & $80 \%$ & $14 \%$ \\
\hline
\end{tabular}

Table 6: Financial management.

\begin{tabular}{|l|l|l|l|l|}
\hline \multicolumn{5}{|l|}{ Energy efficiency } \\
\hline 1. & $\begin{array}{l}\text { Do you monitor expenses on } \\
\text { energy/to target savings on } \\
\text { energy savings? }\end{array}$ & $33 \%$ & $66 \%$ & $1 \%$ \\
\hline Innovation & $\begin{array}{l}\text { Do you initiate budgets for } \\
\text { greening the property? }\end{array}$ & $35 \%$ & $63 \%$ & $2 \%$ \\
\hline 1.
\end{tabular}


Table 7: Administrative management.

\begin{tabular}{|l|l|l|l|l|}
\hline \multicolumn{3}{|l|}{ Energy efficiency } \\
\hline 1. & $\begin{array}{l}\text { Do you keep records on } \\
\text { energy efficiency efforts? }\end{array}$ & $35 \%$ & $65 \%$ & $0 \%$ \\
\hline Innovation & $\begin{array}{l}\text { Do you initiate innovative } \\
\text { green efforts for property } \\
\text { such as competition or green } \\
\text { month campaign? }\end{array}$ & $19 \%$ & $69 \%$ & $12 \%$ \\
\hline 1. & \begin{tabular}{l} 
Dompan \\
\hline
\end{tabular}
\end{tabular}

Table 8: Insurance.

\begin{tabular}{|l|l|l|l|l|}
\hline \multicolumn{4}{|l|}{ Materials and resources } \\
\hline 1. & $\begin{array}{l}\text { Do you take up green policies } \\
\text { for the building? }\end{array}$ & $22 \%$ & $77 \%$ & $1 \%$ \\
\hline
\end{tabular}

Table 9: Health and safety.

\begin{tabular}{|c|c|c|c|c|}
\hline \multicolumn{5}{|c|}{ Energy efficiency } \\
\hline 1. & $\begin{array}{l}\text { Do you have energy efficient } \\
\text { devices for health and safety? }\end{array}$ & $22 \%$ & $78 \%$ & $0 \%$ \\
\hline \multicolumn{5}{|c|}{ Indoor air quality } \\
\hline 1. & $\begin{array}{l}\text { Do you plan for emergency } \\
\text { exits with good indoor air } \\
\text { quality? }\end{array}$ & $58 \%$ & $28 \%$ & $14 \%$ \\
\hline \multicolumn{5}{|c|}{ Innovation } \\
\hline 1. & $\begin{array}{l}\text { Do you have water saving } \\
\text { devices for emergency? }\end{array}$ & $68 \%$ & $32 \%$ & $0 \%$ \\
\hline
\end{tabular}

Table 10: Tenants management.

\begin{tabular}{|c|c|c|c|c|}
\hline \multicolumn{5}{|c|}{ Energy efficiency } \\
\hline 1. & $\begin{array}{l}\text { Do include energy efficiency } \\
\text { measures in the lease } \\
\text { agreement? }\end{array}$ & $11 \%$ & $89 \%$ & $0 \%$ \\
\hline \multicolumn{5}{|c|}{ Indoor air quality } \\
\hline 1. & $\begin{array}{l}\text { Do you ensure indoor air } \\
\text { quality performance by } \\
\text { tenants? }\end{array}$ & $22 \%$ & $71 \%$ & $7 \%$ \\
\hline \multicolumn{5}{|c|}{ Materials and resources } \\
\hline 1. & $\begin{array}{l}\text { Do you encourage tenants to } \\
\text { use biodegradable materials? }\end{array}$ & $7 \%$ & $89 \%$ & $4 \%$ \\
\hline \multicolumn{5}{|c|}{ Water efficiency } \\
\hline 1. & $\begin{array}{l}\text { Do you program for water } \\
\text { saving efforts? }\end{array}$ & $67 \%$ & $27 \%$ & $6 \%$ \\
\hline \multicolumn{5}{|c|}{ Innovation } \\
\hline 1. & $\begin{array}{l}\text { Do you encourage } \\
\text { sustainability campaign? }\end{array}$ & $78 \%$ & $15 \%$ & $7 \%$ \\
\hline
\end{tabular}




\section{FINDINGS}

The purpose of this survey is to answer some of the research questions put forward in the proposals. In the earlier chapters, it was alleged that this research was approached with a holistic view of the concept of green property management. Firstly, there is a need to examine the structure within which GPM operates. This are the rules related to the practice as described earlier. The analysis for determining behaviours of agents in GPM is based on frequencies. This is to get a general picture of agents' behaviour in implementing GPM. There are three aspects that are important. Firstly, the driving forces for GPM. Secondly is to how they view the important aspect of GPM which is the energy and water saving. Finally, there is a need to see what are considered to be less important.

The ability to distinguish agents' behaviours in GPM is important, as they are the variables that will determine GPM practices. The driving force for GPM, which are the rules affecting their actions, the facilities and other constraints towards GPM will determine the success or failure of GPM. The following information analyses the effect of attitudes and behaviours on GPM.

According to the survey conducted, the majority of the respondents are keen on GPM with more than half adopting green policies to support green management practices. The drives for GPM are mainly driven by economic pressure. The economy may either provide incentives or disincentives for adopting GPM. The incentives may either be in the form attractive rentals and high-profile tenants. The economic disincentives may be due to the high cost of installing devices for energy and water control or using green materials. Other factors that have an impact on the practice of GPM are the legal as well as other social factors. In preparing the management plans, the response showed that many of the green aspects are being considered in their management plans suggesting that managers are quite particular on the issues of sustainability and included the green criteria elements in their plan. The same pattern appeared when managing buildings; the majority considered green elements in managing properties. Some of the green criteria that had less consideration in the building management were the use of SOP for GPM and the use of green materials for managing buildings.

From the survey, the other aspects of property management such as administrative, financial, health and safety and tenants' management were not adopted by managers. This suggests that they do not believe that these are important for GPM. They may not have important impact on GPM. The survey revealed some of the important findings on GPM practice. Firstly, the most important elements in GPM are the energy saving and water saving functions. Installing devices may help to facilitate this. Nevertheless, since the economy is the main driving force for GPM, property/building managers may have to appraise the savings against the cost of installation. Other small efforts for supporting GPM are the use of energy efficient bulbs for lighting. Having examined the mechanism for GPM, the inclusion of green criteria in managing buildings can actually be practiced if managers and owners are serious about it. The analysis shows that the majority of the respondents apply some elements of green criteria in managing buildings and only a few (10-20\%) adopt all the criteria for GPM. This suggests that they may be managing green buildings. The main concern is the management of conventional buildings and adopts the green practice. There may be problems that will deter the push towards practicing GPM. What these problems and constraints are will need to be examined further and in detail as the survey did not give much information.

This section manages to achieve two objectives for this research. The first objective identified the current practice of green property management concept in terms of Green Building Index (GBI). This was achieved in the earlier parts of the chapter where the 
elements of GBI are positioned accordingly with the property management standards and a tool for assessment was developed.

Using the tool, a survey was done to find out the attitude of major participants in the industry particularly the property managers. This was one of the objectives attained in the research. The findings of the survey showed that the main important elements in GPM are energy and water efficiency and that many of the respondents to the survey have somehow adopted the GPM. This showed that property and building managers were concerned with saving the environment. Nevertheless, the economic considerations for not following GPM are some of the constraints faced in GPM practices. Although the survey had shown some indication on agents' behaviours in GPM, it did not provide the in-depth explanation on the outcome of the property management problems. There seemed to be other elements that could have contributed towards the outcome of the GPM process; an in-depth investigation using case study is required to be able to understand the whole process.

\section{SUMMARY}

This research started with some questions on the extent of Green Property Management in Malaysia. Investigations on including green practices in property management require further work particularly at the implementation stage as it requires all parties to agree with this move. The legislation for the implementation of Green Property Management must be clearly drawn up. The benefits derived from green practice must be made public and the dangers of not going green must also be stated. Nowadays, the growth and development of our communities have made a large impact on our natural environment and also our health. It is time to make the building or property managers much more aware and responsible in managing their buildings by implementing any approach that can minimise the impacts on the natural environment and our health. With help from government, the policy maker needs to come up with this Green Property Management concept by providing a structured and proper framework. A well-designed Green Property Management framework will help convince and encourage the property or building manager in implementing the green management concept for their building.

\section{REFERENCES}

[1] Razali, M.N., Kamarudin, N., Zainuddin, A.Z. \& Othman, S.H., Green property management for commercial buildings. WIT Transactions on The Built Environment Sustainable Development, pp. 133-143, 2015.

[2] HKPC, Annual Report 2013-2014 Hong Kong Productivity Council, 2014.

[3] Jones Slang La Salle, Sustainable value in a changing world, 2011.

[4] Mebratu, D., Sustainability and sustainable development: historical and conceptual review. Environmental impact assessment review, 18(6), pp. 493-520, 1998.

[5] Karshenas, M., Environment, technology and employment: towards a new definition of sustainable development. Development and Change, 25(4), pp. 723-756, 1994.

[6] Goodland, R., The concept of environmental sustainability. Annual review of ecology and systematics, pp. 1-24, 1995.

[7] Holdren, J.P., Daily, G.C. \& Ehrlich, P.R., The meaning of sustainability: biogeophysical aspects. Defining and measuring sustainability: the biological foundations (eds Munasinghe M., Shearer W.), pp. 3-17, 1995.

[8] Shiers, D., Lavers, A. \& Keeping, M., Indicators of the impact of environmental factors on UK construction law: developments in the new millennium. Construction Management and Economics, 25(7), pp. 821-829, 2007. 
[9] Wilkinson, S., Sustainable retrofit potential in lower quality office stock in the central business district, in MISBE. Proceedings of the International Conference on Management and Innovation for a Sustainable Built Environment, Delft University of Technology, Delft, The Netherlands, pp. 1-13, 2011.

[10] Newell, G. \& Manaf, Z., The significance of sustainability practices by the Malaysian property sector. Local Economy, 23(3), pp. 152-167, 2008. 